\title{
KARST TOPOGRAPHY ON STAGNANT GLACIERS
}

\author{
By Lee Clayton* \\ (Geology Department, University of Canterbury, Christchurch, New Zealand)
}

\begin{abstract}
Karst topography may occur on stagnant, drift-covered parts of glaciers such as the Martin River Glacier in south-central Alaska. Glacial karst features there include ice sink-holes. tunnels, caves, sinking streams, blind valleys, large springs, natural bridges, lapiés, hums, and residual "soils" or ablation till. The glacial karst cycle is essentially the same as the limestone karst cycle. Glacial karst is rare today but was widespread on stagnant glaciers in areas such as the northern Great Plains of North America in late Wisconsin time.
\end{abstract}

RÉsumÉ. La topographie karstique peut se rencontrer dans les parties mortes et recouvertes de moraines des glaciers tel que celui de Martin River au sud du centre de l'Alaska.

Le karst glaciaire est caractérisé à cet endroit par des dolines, des galeries, des souterrains, des lits affaissés, des vallées en cul de sac, des sources abondantes, des ponts naturels, des lapiez, des hums, des "sols" résiduels ou des terrains erratiques d'ablation. Le cycle du karst glaciaire est essentiellement le même que le cycle karstique calcaire. Le karst glaciaire est actuellement rare, mais était largement répandu dans les glaciers morts dans les régions comme la partie nord de la Grande Plaine d'Amérique
du Nord à l'âge du Wisconsin.

Zusammenfassung. Karstähnliche Oberflächenformen können an stagnierenden, schuttbedeckten Teilen von Gletschern vorkommen, wie z.B. am Martin River Glacier im südlichen Zentral-Alaska. Glaziale Karst-Erscheinungen umfassen dort Dolinen, Tunnels, Höhlen, versickernde Wasserläufe, Sacktäler, starke Quellen, Naturbrücken, Karren, Hums und "Restböden"” oder Ablationsschutt. Der glaziale KarstZyklus ist im wesentlichen derselbe wie der im Kalkstein. Glazialer Karst tritt heute selten auf, war aber in der späten Wisconsin-Eiszeit weitverbreitet auf stagnierenden Gletschern in Gebieten wie den nördlichen Grossen Ebenen von Nordamerika.

\section{INTRODUCTION}

The topography on glaciers is not generally thought of in terms of the karst cycle, and karst terminology is seldom applied to the topographic features of glaciers (Charlesworth, I957, p. $5^{8}$ and $6 \mathrm{I}$ ). However, solution features do form on soluble rocks other than limestone and dolomite (gypsum and rock salt, for example), and Gravenor (1955, p. 476-77) has suggested that a stagnant ice sheet is in many respects similar to a limestone formation, and may develop "ice-sinks" when the roofs of ice caves collapse. Although the process involved on glaciers is melting rather than solution, the results are nearly the same, and (especially on stagnant, drift-covered glaciers) most of the usual karst features may result.

Well-developed karst topography is found on only a few present-day glaciers. It is especially conspicuous on the stagnant and drift-covered margin of the Malaspina Glacier in southern Alaska, where it has been described in detail by Tarr and Martin (1914, p. 205-28) and Russell (I90I, p. I I2-2 I), who, however, did not use karst terminology. The Martin River Glacier, $200 \mathrm{~km}$. west of the Malaspina, is used in the discussion that follows to illustrate well-developed glacial karst; it was investigated during June, July, and August i962.

Karst topography was apparently more widespread on former glaciers. During late Wisconsin time continental glaciers in large parts of Saskatchewan, Alberta (Gravenor and Kupsch, I959), and North Dakota (Clayton, i 963), stagnated on a large scale. In these and similar areas the glacial karst topography resulted in the formation of dead-ice moraine and other associated stagnation landforms. An understanding of how karst topography develops on present-day glaciers is therefore important in interpreting these significant landforms in the northern Great Plains.

\section{Conditions Negessary for the Formation of Glacial Karst}

Thornbury (1954, p. 31 7-18) lists four conditions necessary for the formation of karst topography:

* Present address: Department of Geology, University of Illinois, Urbana, Illinois, U.S.A. 
I. Soluble rocks. Glacial ice is melted rather than dissolved, but for purposes of karst formation melting gives the same results. jointed.

2. Dense, highly jointed rocks. Glacier ice is dense and impermeable and is usually well

3. Low ground-water base level. Glacial karst topography forms only where the melt water can seep through the glacier and be drained away from the margin.

4. At least moderate rainfall. Glacial melt water adds to or takes the place of moderate rainfall.

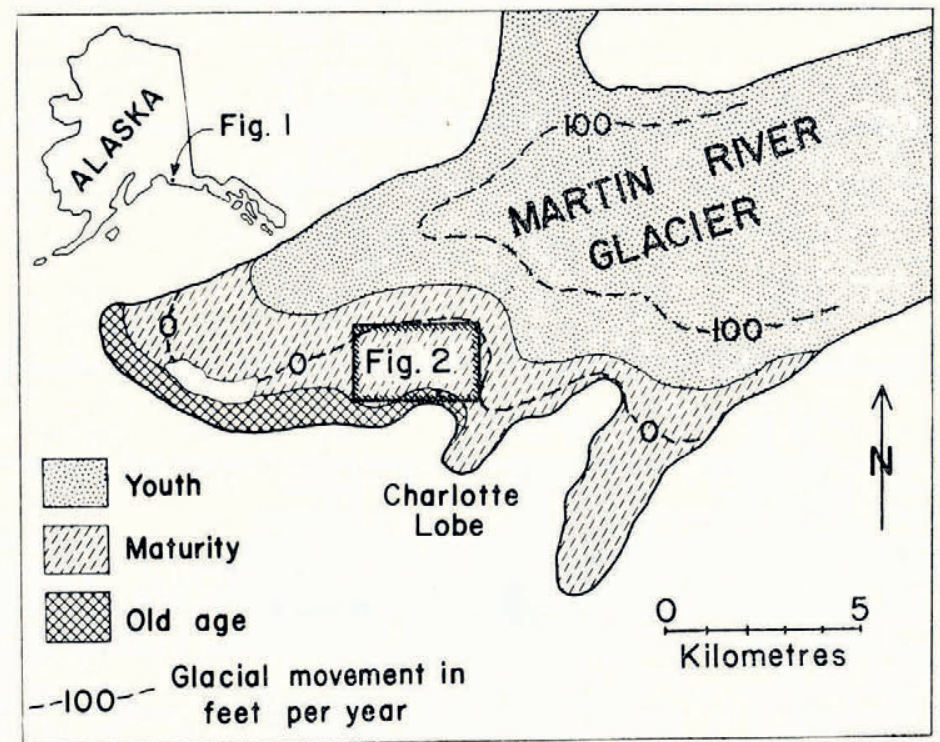

Fig. I. Map of Martin River Glacier showing stage of karst cycle. Movement was scaled from air photographs taken in 1950 and 1957 by the U.S. Geological Survey; limit of zone of no movement is, in part, based on geomorphic evidence

In addition the glacier must be stagnant and drift-covered. If it were not stagnant the glacier movement would destroy any karst topography before it cculd fully develop. A cover of ablation till is required because its insulating effect decreases general surface ablation and preserves the stagnant glacier long enough for the more local karst ablation to form full-scale karst features. The irregular cover of ablation till also increases the irregularity of melting of the surface of the nearly homogeneous glacier ice.

\section{Martin River Glacier}

The Martin River Glacier, between the Copper River delta and the Bering Glacier in south-central Alaska, is an example of a glacier with well-developed karst topography (Fig. I). Twenty-four kilometres above its terminus the glacier leaves the Chugach Mountains and spreads out into a piedmont or expanded-foot glacier, which is confined between the mountains and the foothills. Here it is as much as $10 \mathrm{~km}$. wide. The terminal $4 \mathrm{~km}$. are covered with superglacial ablation till varying in thickness from several centimetres near the centre to more than $3 \mathrm{~m}$. along the outer edge of the glacier. The terminal i to $3 \mathrm{~km}$. of the glacier are stagnant.

Most of the ablation till originated by the concentration of subglacial debris that had been carried up into the glacier along imbricate thrust planes where the active ice was thrust up over less active or stagnant ice. The cover of ablation till causes the lower end of the glacier 
to melt much more slowly than the cleaner parts of it; the most recently formed marginal moraine is adjacent to the lower end of the glacier, but it is well above the glacier several kilometres from its terminus - the slope of the upper surface of the glacier is becoming flatter and the lobe is becoming much thinner but maintaining a constant length. This results in increased terminal stagnation. Active ice is being thrust up over this newly stagnant ice, dragging more subglacial debris into the upper parts of the glacier, thus increasing the thickness of the ablation till. This new ablation till, in turn, further decreases melting, lowers surface slope, increases thinning of the lobe, and so forth. Thus, the stagnant part of the

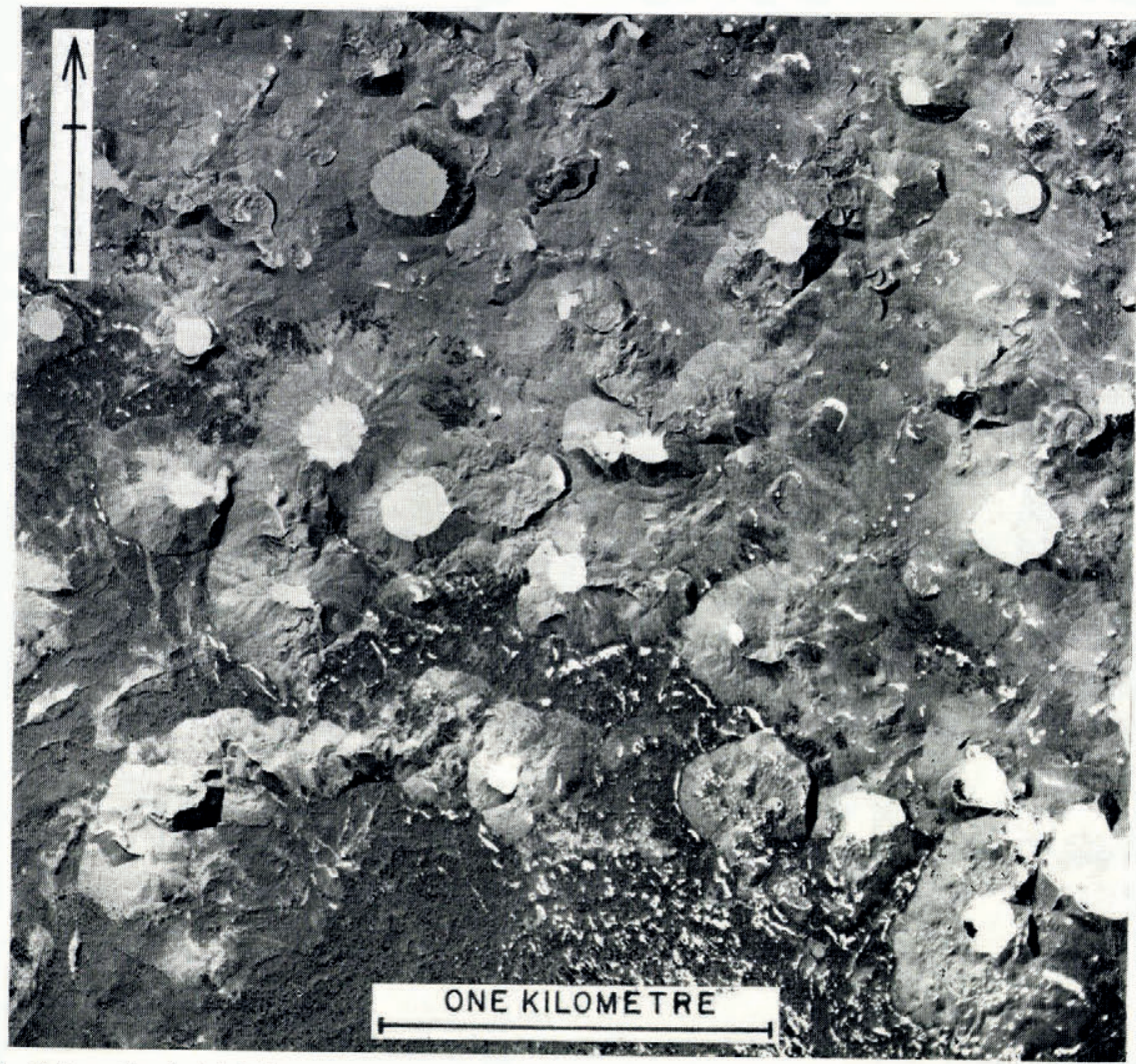

Fig. 2. Air photograph of sink-holes on stagnant to nearly stagnant part of Marlin River Glacier (see Fig. I). Photograph EEV-I.5-I 8 taken 12 June 1959 by the U.S. Department of Agriculture Forest Service

glacier is, in part at least, self-perpetuating. Well-developed glacial karst features therefore have had an opportunity to be formed over most of this terminal part of the Martin River Glacier.

\section{Glacial Karst Features}

The most striking karst features on the Martin River Glacier are funnel-shaped sink-holes, As can be seen in Figure 2, most are 60 to $370 \mathrm{~m}$. across, and there are as many as thirty in a square kilometre. They are 15 to $90 \mathrm{~m}$. deep and many hold small lakes. Sink-holes are also the most conspicuous karst feature on the stagnant part of the Malaspina Glacier (Russell, I901, p. I I $5^{-1} 7$ ). 
Funnel-shaped sink-holes apparently were also very abundant on some parts of the stagnant glaciers in the northern Great Plains of North America in late Wisconsin time. Where the ablation till was thick and had a high silt and clay content, it flowed into the sinkholes and, when the glacial topography was inverted, formed the "prairie mounds" and "circular disintegration ridges" that are common there today (Gravenor, 1955; Gravenor and Kupsch, I959, p. 52-53).

Many variations from the simple funnel-shaped sink-hole occur on the Martin River Glacier. Two or more commonly coalesce to form compound sink-holes. Several examples of karst windows, or the unroofed parts of subglacial streams, occur. Some karst windows have enlarged to form glacial uvallas; a stream flows from one side of the uvalla, across its gravel bottom, and into another tunnel at the other side. A lake $2 \frac{1}{2} \mathrm{~km}$. long and $\frac{3}{4} \mathrm{~km}$. wide near the terminus of the glacier occupies a superglacial polje. The glacial uvallas and poljes that are bottomed on solid ground and floored with lake sediment or outwash may result in landforms that are nearly identical to the "ice-walled outwash plains" and "ice-walled lake plains" in North Dakota (Clayton, 1963). Another type of glacial sink-hole on the Martin River Glacier is the shaftlike sink-hole or moulin. It is the result of "solution" alone, rather than collapse. Moulins are not funnel-shaped depressions but are vertical cylindrical holes a few metres in diameter and probably more than $30 \mathrm{~m}$. deep. They are abundant only on the active part of the glacier.

Other karst features that are extremely abundant in the Martin River Glacier are ice caves and tunnels. In the stagnant part of the glacier most of the drainage is subglacial and is continually shifting as tunnels are abandoned and new ones formed. Many of the caves and tunnels are $3 \mathrm{~m}$. or more high and more than $2 \mathrm{~km}$. long. One small network of tunnels near the end of the "Charlotte lobe" (see Fig. I) of the Martin River Glacier was explored. It was floored with gravel, in places had gravel terraces along its sides, and had one or two side tunnels that were completely clogged with gravel. Conspicuous occurrences of superposed ice and icicles - the glacial equivalent of drip-stone and stalactites - were not observed in any of the ice caves during the summer; moisture and a "thumb-print" surface (Charlesworth, 1957 , p. $5^{8}$ ) on the walls of the caves indicate that summer ablation inside the caves is too high for their preservation.

Other common karst features on the Martin River Glacier include sinking streams, dry stream beds, blind valleys, and large springs. Small natural bridges occur in some places. Lapiés, an "etched, pitted, grooved, fluted, and otherwise rugged surface" (Thornbury, r 954, p. 319), occurs in many places but is not as well developed as in limestone karst areas. The equivalent of hums - the erosional remnants of limestone-are the isolated blocks of ice beyond the end of the glacier; these glacial hums may become covered with outwash and then melt out, forming kettles.

Ablation till is the glacial karst equivalent of the residual soils, including "terra rossa", that accumulate in limestone karst areas. Both ablation till and the residual soils consist of the "non-soluble impurities" in the "dissolved" rock, and both increase in thickness as the karst cycle progresses. Little life exists where the ablation till is only centimetres thick near the centre of the Martin River Glacier, but stunted spruce, hemlock, alders, and willows grow where it is $\frac{1}{2} \mathrm{~m}$. thick. Thick alder scrub covers the ablation till where it is $\frac{1}{2}$ to $\mathrm{I} \frac{1}{2} \mathrm{~m}$. thick. The ablation till is very unstable in this area; it is constantly sliding down the steep sides of the numerous sink-holes. Where the ablation till is $1 \frac{1}{2}$ to $3 \mathrm{~m}$. or more thick it is very stable and supports a full grown spruce-hemlock forest that is more than roo years old. In this stable area the lakes in the large sink-holes are well insulated from the glacier by the ablation till; they are warm and clear and support the normal freshwater plants and animals of the region. In parts of the northern Great Plains in late Wisconsin time the superglacial ablation till was also apparently quite thick; it was let down when the glaciers melted to form the widespread dead-ice moraine (Gravenor and Kupsch, I959; Clayton, I963). 
It can thus be seen that most karst features found in limestone areas may also occur on glaciers, especially stagnant, drift-covered ones. Where these features occur in great abundance the resulting topography can logically be referred to as "karst topography".

\section{Karst Cycle}

The karst cycle, as summarized by Thornbury (1954, p. 349-52), can also be applied to glaciers as well as to limestone areas. The glacial karst cycle, as illustrated by the Martin River Glacier, is outlined in Table I. The cycle begins when the ice is exposed from under

\begin{tabular}{ll}
$\begin{array}{l}\text { Stage: } \\
\text { Characteristic karst } \\
\text { features: } \\
\text { Drainage: }\end{array}$ & \multicolumn{1}{c}{$\begin{array}{c}\text { Youth } \\
\text { Shaft-like sink- } \\
\text { holes (moulins) } \\
\text { Much surface }\end{array}$} \\
$\begin{array}{l}\text { Superglacial ablation } \\
\text { till: }\end{array}$ & $\begin{array}{l}\text { None, except in } \\
\text { medial moraines }\end{array}$ \\
$\begin{array}{l}\text { Plants on ablation } \\
\text { till: }\end{array}$ & None or very few \\
Lakes: & None
\end{tabular}

Glacial movement: Active

Table I. The Glacial Karst Cycle on the Martin River Glacier; Area covered by EAch Stage Shown in Figure I

Maturity
Funnel-shaped sink-holes,
tunnels
Largely sub-surface

First several centimetres, later a metre or more thick; unstable

First a few stunted plants; later thick alder scrub

In funnel-shaped sink-holes; cold and silty; barren

Slightly active to stagnant

\begin{abstract}
Old age
Karst windows, uvallas, poljes, hums

Becoming surface again as ice disappears

$1 \frac{1}{2} \mathrm{~m}$. to more than $3 \mathrm{~m}$. thick; stable

Spruce-hemlock forest

In coalesced sink-holes, uvallas, and poljes; insulated from ice by ablation till; warm and clear; freshwater plants and animals

Stagnant
\end{abstract}

the melting firn; it progresses to maturity as the drainage becomes sub-surface, the glacier stagnates, the ablation till thickens, and funnel-shaped sink-holes become conspicuous; and it ends when the last ice hums have melted and the drainage is again at the surface.

\section{Summary}

Most of the features that constitute karst topography in limestone areas can also occur on stagnant glaciers. Limestone and glacial karst features form by similar processes, and they both evolve through the same karst cycle. Although glacial karst topography occurs today in only a few places, such as the lower ends of the Martin River and Malaspina Glaciers, it commonly occurred in late Wisconsin time in the northern Great Plains of North America and was responsible for many of the glacial landforms that occur there today.

\section{Acknowledgement}

The Martin River Glacier was studied during the summer of 1962 by a University of North Dakota party under the support of the National Science Foundation. Other members of the party, besides myself, were Dr. W. M. Laird, Dr. J. R. Reid, and Mr. S. J. Tuthill, whom I thank for reading and criticizing the manuscript of this paper.

MS. received 5 June 1963

\section{R E F E R E N C E S}

Charlesworth, J. K. 1957. The Quaternary era, with special reference to its glaciation. London, Edward Arnold.
2 vols.

Clayton, L. 1963. Glacial geology of Logan and McIntosh Counties, North Dakota. Bulletin of the Norlh Dakota
Geological Survey, Vol. 37. 
Gravenor, C. P. 1955. The origin and significance of prairie mounds. American fournal of Science, Vol. 253, No. 8,

p. $475-8 \mathrm{I}$.
Gravenor, C. P., and Kupsch, W. O. 1959. Ice-disintegration features in western Canada. Journal of Geology, Vol. 67, No. I, p. 48-64.

Russell, I. C. Igor. Glaciers of North America. Boston, Ginn and Co.

Tarr, R. S., and Martin, L. 1914. Alaskan glacier studies of the National Geographic Society in the Yakutat Bay, Prince William Sound and lower Copper River regions. Washington, National Geographic Society.

Thornbury, W. D. 1954. Principles of geomorphology. New York, John Wiley and Sons, Inc.; London, Chapman and Hall, Ltd. 